\title{
THE ROLE OF STUDENT LOANS SUBSIDIZED BY THE STATE IN THE SLOVAK BANKING SECTOR \\ Mária Barteková ${ }^{1}$ L'udomír Šlahor $^{2}$
}

\begin{abstract}
The aim of this paper is to analyse student loans subsidized by the state in Slovakia and their role in the Slovak banking sector. There has been a slight increase in the Slovak banking market, especially the share of small and mediumsized banks. Student loans ensure equal educational opportunities for all students. Four years of a student loan provision in Slovakia can be briefly characterised as a socially oriented approach. The Slovak government, the founding owner of the Education Support Fund, has implemented numerous changes concerning the clients in the borrowing as well as in the repayment phase. The empirical analysis in this paper consists of the descriptive statistics focused on the Slovak student loan market and the financial analysis of the banking sector providing student loans in Slovakia. The most significant finding that emerged from our analysis is to provide every student enrolled in higher education with the information on accessible student loans with a low interest rates. The achieved results prove the decreasing role of student loans subsidized by the state within the Slovak banking market. However, the profitability of the Education Support Fund was significantly higher than the figure achieved by the Slovak banking sector in 2017.
\end{abstract}

JEL Classification Numbers: G10, G21, H59; DOI: http://dx.doi.org/10.12955/cbup.v6.1130

Keywords: financial market, student loans, the Slovak banking sector

\section{Introduction}

In general, banks are the most visible and the most influential financial intermediaries (Cecchetti and Schoenholtz, 2015). The banking market in Slovakia was influenced by political development. Nowadays, Slovakia has been enjoying a significant economic growth. In 2016, the economy grew by $3.3 \%$, which was one of the highest growths in the EU. The main driver was private consumption supported by a decreasing unemployment rate and a low interest rate environment. The unemployment rate has fallen for the fourth consecutive year to $8.8 \%$ and real wages grew by almost $4 \%$ (Rentková and Panevski, 2017).

Since 2013, the Education Support Fund - a Slovak student loan provider, has been supporting tertiary students and helping their families to pay the expenses connected with the studies. The conditions of the loan can differ according to the design of the student loan system. A typical element is the interest rate subsidized by the state, which allows a student to repay the loan at a lower interest rate than the existing market rate (Heitor et al., 2016). On the other hand, it is important for a student to weigh the decision to borrow for college considering the costs and benefits (Henager and Wilmarth, 2018).

The Slovak banking market consists of 27 financial institutions (European Banking Federation, 2018). Since 2001 most of the banks in Slovakia have been controlled by foreign entities, mainly international banking groups from Austria, Italy and Belgium (European Banking Federation, 2018). However, four banks are fully under the control of domestic investment groups.

In the long term, higher levels of credit to GDP are generally associated with higher economic growth (Beck et al., 2012, Sahay et al., 2015). Arcand et al. (2015) found that a financial debt begins to dampen output growth when credits to the private sector reach between $80 \%$ and $100 \%$ of GDP.

Retail loans have become predominant in the domestic lending market and Slovakia has one of the highest growth rates in retail loans in the EU. In 2016 the outstanding amount of consumer credits and housing loans rose by 14\% year-on-year (European Banking Federation, 2018). The main factors which have been increasing the households' interest in loans are very low interest rates and rising disposable incomes. The banks looking to diversify their loan portfolio should do so with caution (Goenner, 2018). Since the year 2010 the percentage of non-performing loans to the total amount of gross loans has been decreasing, exactly as in case of the Education Support Fund. In order to earn a profit and to be able to offer loans to customers, banks need to minimize the amount of nonperforming loans. The non-performing loans are harmful to the banking business (Miller and Nikaj, 2018). The empirical facts provided by the Education Support Fund confirm that the non-performing loan rate is below $1 \%$ of the value of the Education Support Fund's portfolio.

\footnotetext{
${ }^{1}$ Faculty of Management, Comenius University in Bratislava, maria.bartekova@ fm.uniba.sk

${ }^{2}$ Faculty of Management, Comenius University in Bratislava, ludomir.slahor@fm.uniba.sk
} 


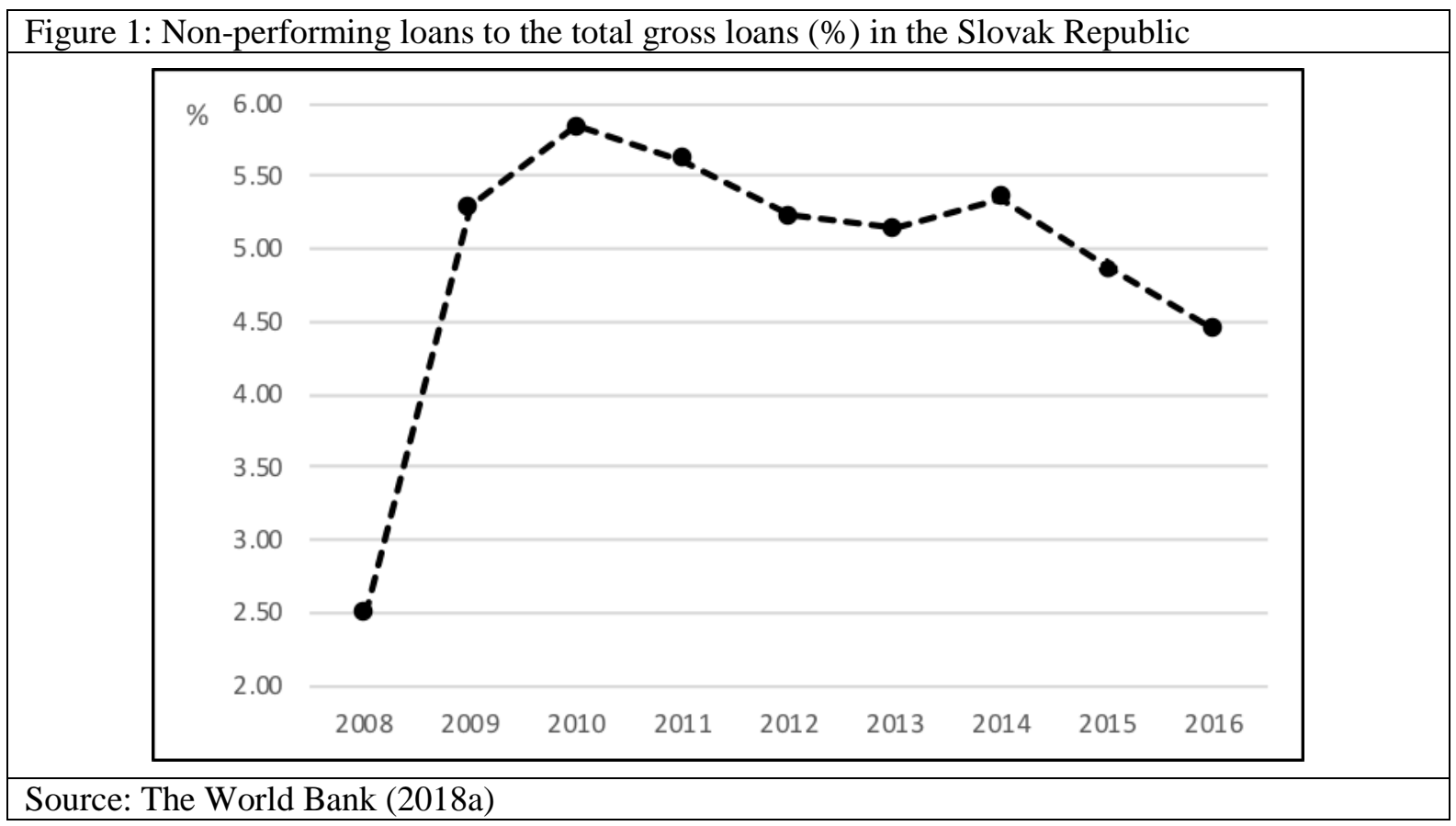

A protracted period of low and negative policy rates and flat yields could undermine financial resilience in the medium term, but the risks of increased headwinds may materialize more immediately (The International Monetary Fund, 2018).

Domestic credit provided by the financial sector includes all credit to various sectors on a gross basis, with the exception of credit to the central government, which is net (The World Bank, 2018c). At low levels of economic development, commercial banks tend to dominate the financial system, while at higher levels, domestic stock markets tend to become more active and efficient (Ding, Li and Feng, 2014). Robust financial systems can increase economic activity and welfare, but instability can disrupt financial activity and impose widespread costs on the economy (The World Bank, 2018c). As one can see, the role of the financial sector in Slovakia was increasing from 2006 to 2016 (Figure 2). The growth of more than $27 \%$ was linked to the development of the Slovak economy.

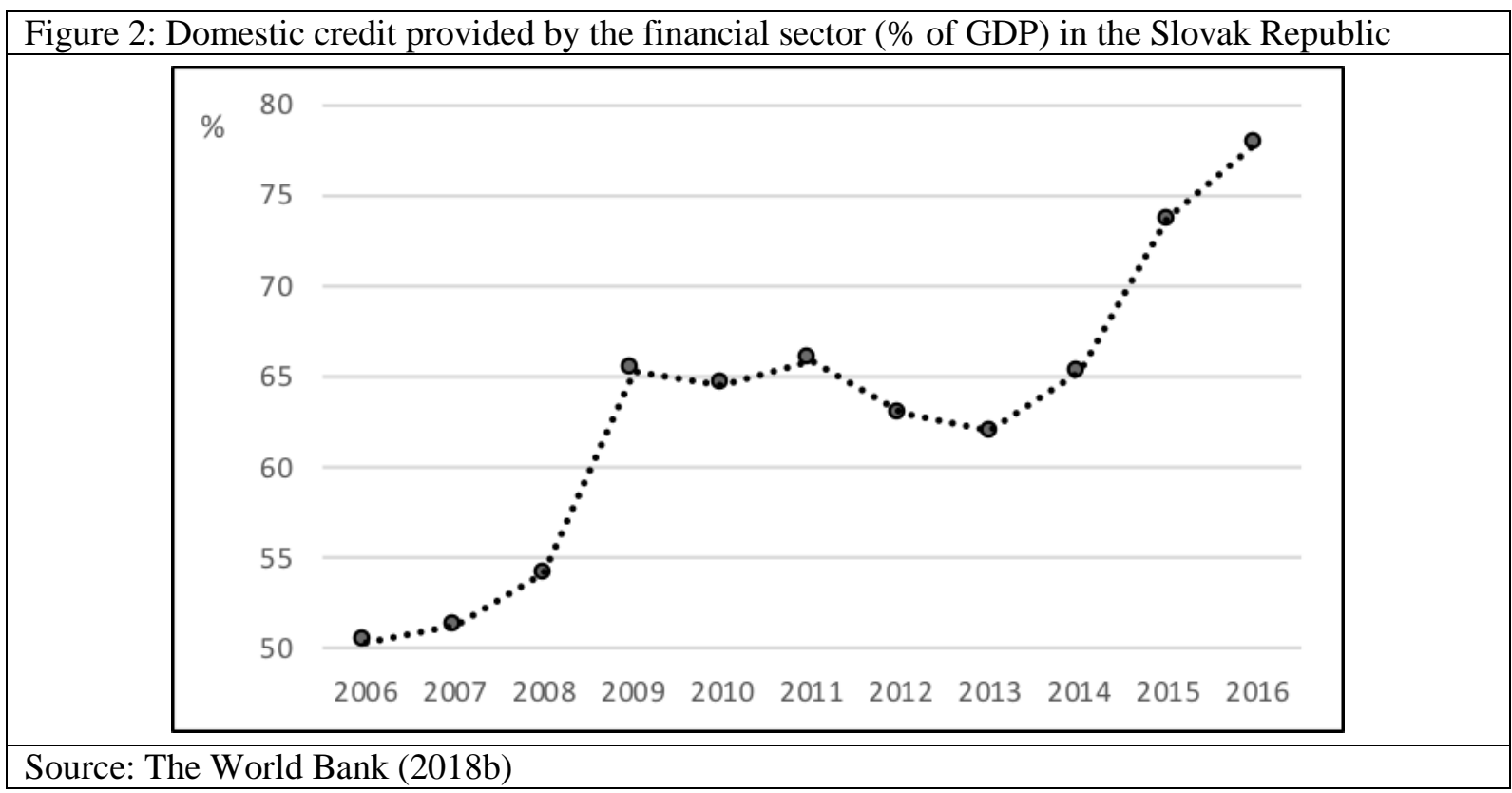

Loans (Cecchetti and Schoenholtz, 2015) are the primary asset of modern commercial banks, accounting for well over one half of their assets. Cecchetti and Schoenholtz (2015) divide loans into five broad categories: 
- business loans, commercial and industrial loans,

- retail estate loans, including both home and commercial mortgages as well as home equity loans,

- consumer credits, such as a loan for a car purchase and credit card loans,

- interbank loans (loans made from one bank to another),

- and other types, including the loans for purchase of other securities.

Other types of retail loans have long had only a marginal impact on the rate of change in the stock of retail loans, and their volume has remained unchanged for the past two years. These loans include overdraft facilities, revolving loans, credit cards, and other loans. In aggregate terms, they amounted to EUR 2.3 billion, i.e. $8 \%$ of the stock of retail loans as at December 2016.

The annual rate of growth in consumer credits slowed in relative terms, while remaining virtually unchanged in absolute terms (Cifter, 2015). The rate of relative growth slowed during the year, from almost $16 \%$ to $13.8 \%$ in December. In absolute terms, consumer credits continued to grow, by roughly EUR 550 million. This was persistently the most rapid growth in consumer credits during the Euro period. New lending in this sector was increasingly dominated by consumer credits with a maturity of over seven years (the recommended limit is eight years), with the share increasing from about $60 \%$ to more than $70 \%$ in two years. The share of refinancing new loans exceeded by $80 \%$ in the last quarter of 2016. This was in line with the long-term trends that deepened even further (The National Bank of Slovakia, 2018a).

\section{Data and Methodology}

The aim of this paper is to analyse student loans subsidized by the state in Slovakia and their role in the Slovak banking sector. We have drawn our attention to the data from The World Bank Database, the European Commission Database (Eurostat) and the Education Support Fund in order to monitor how student loans developed between 2013 and 2017. We have also quantified the trends and estimates in the banking sector, which can influence granting student loans in Slovakia.

The Education Support Fund - a Slovak student loan institution, is a non-state special-purpose fund established in 2013. The Education Support Fund provides loans to the students studying in Slovakia in higher grades and Slovak students studying abroad. The main characteristics of the student loans provided by the Education Support Fund are as follows:

- A student loan may be used at the borrower's discretion.

- No credit assessment is needed. No guarantee or other coverage is required. They are accessible to every student actively enrolled in higher education.

- A maximum EUR 2,300 may be applied for per academic year regardless of the type of course. The loan is transferred in a lump sum in December.

- This type of a student loan is a fixed interest rate loan. Its interest rate was $3.00 \%$ in the academic year 2017/2018.

- Repayment normally begins only in the second month following termination of the student status. The repayment rules were established in a way to make repayment flexible and easy to be met. Moreover, it is also possible to reduce repayment temporarily and use the opportunity of various allowances.

Retail interest rates - Creating deposit and lending rates is based on the assumption that a change of key rates in the European Central Bank is reflected in the interbank interest rates first and only subsequently in the retail rates (The National Bank of Slovakia, 2018a).

\section{Results and Discussion}

In the banking sector, asset growth was driven by a strong demand for household loans in 2016 (The National Bank of Slovakia, 2018a). The most frequent type of loan is the loan for house purchases. Student loans are included in the fourth biggest category of commercial loans - the loans for consumption (Figure 3). A loan for consumption is an equity release loan (without stating a purpose of loan. The loans are used according to the borrower's personal decision. The maturity of the loans for consumption is between 5 and 10 years. 


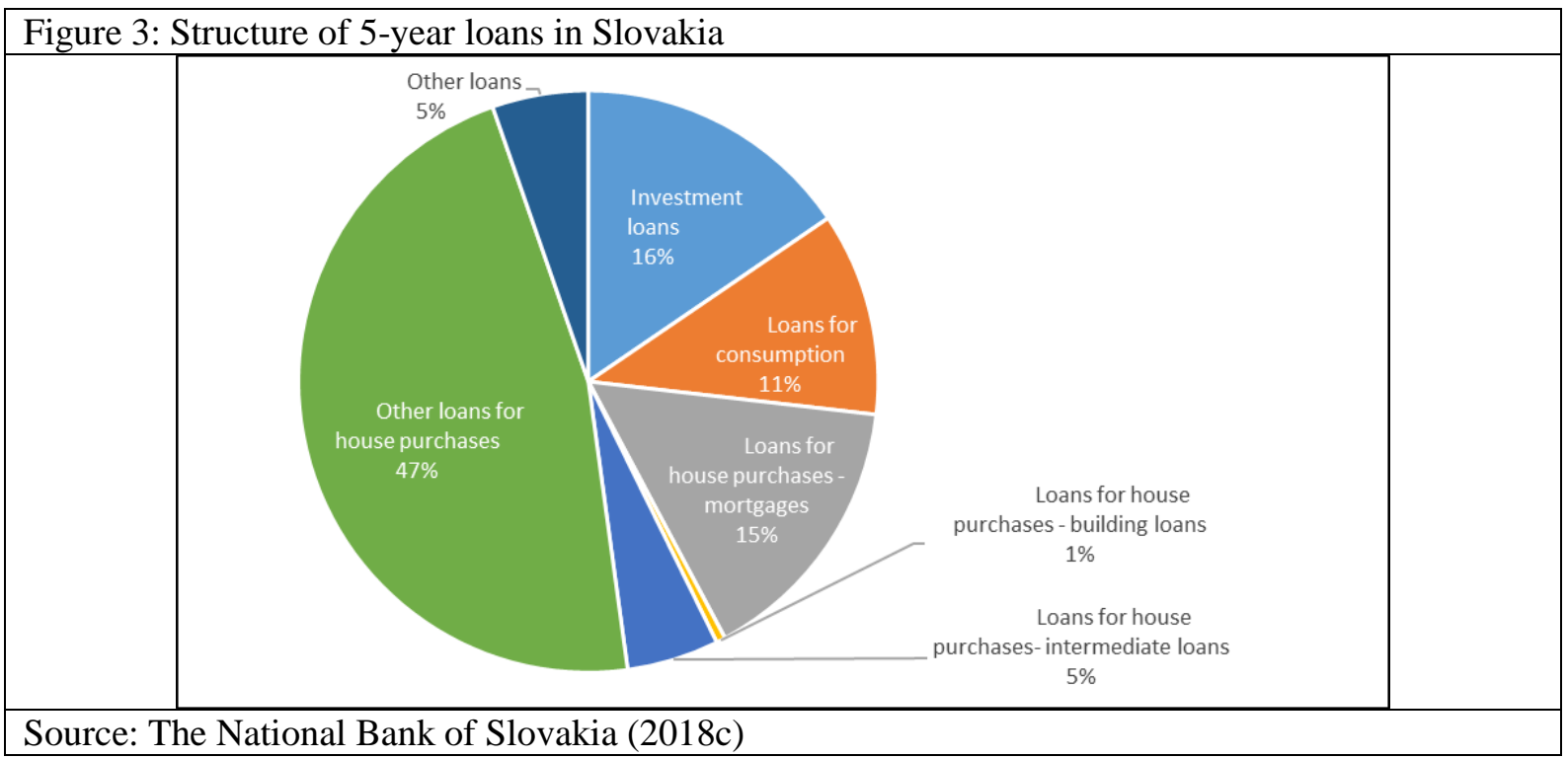

The National Bank of Slovakia (2018a) recorded that the average lending rate reached $9.0 \%$ in December 2016, while the annual percentage rate of charge varied around $9.7 \%$. The average interest rate on the stock of loans remained $1.5 \%$ above the average rate for new loans (The National Bank of Slovakia, 2018a).

Due to the lack of financial resources, the overall amount of student loans has been decreasing from the beginning of the Education Support Fund (Figure 4). It will be possible to only allocate annually a maximum of EUR 2.8 million to grant to tertiary students without state financial support. The development of the interest rates was influenced by very low interest rates in the Slovak financial market.

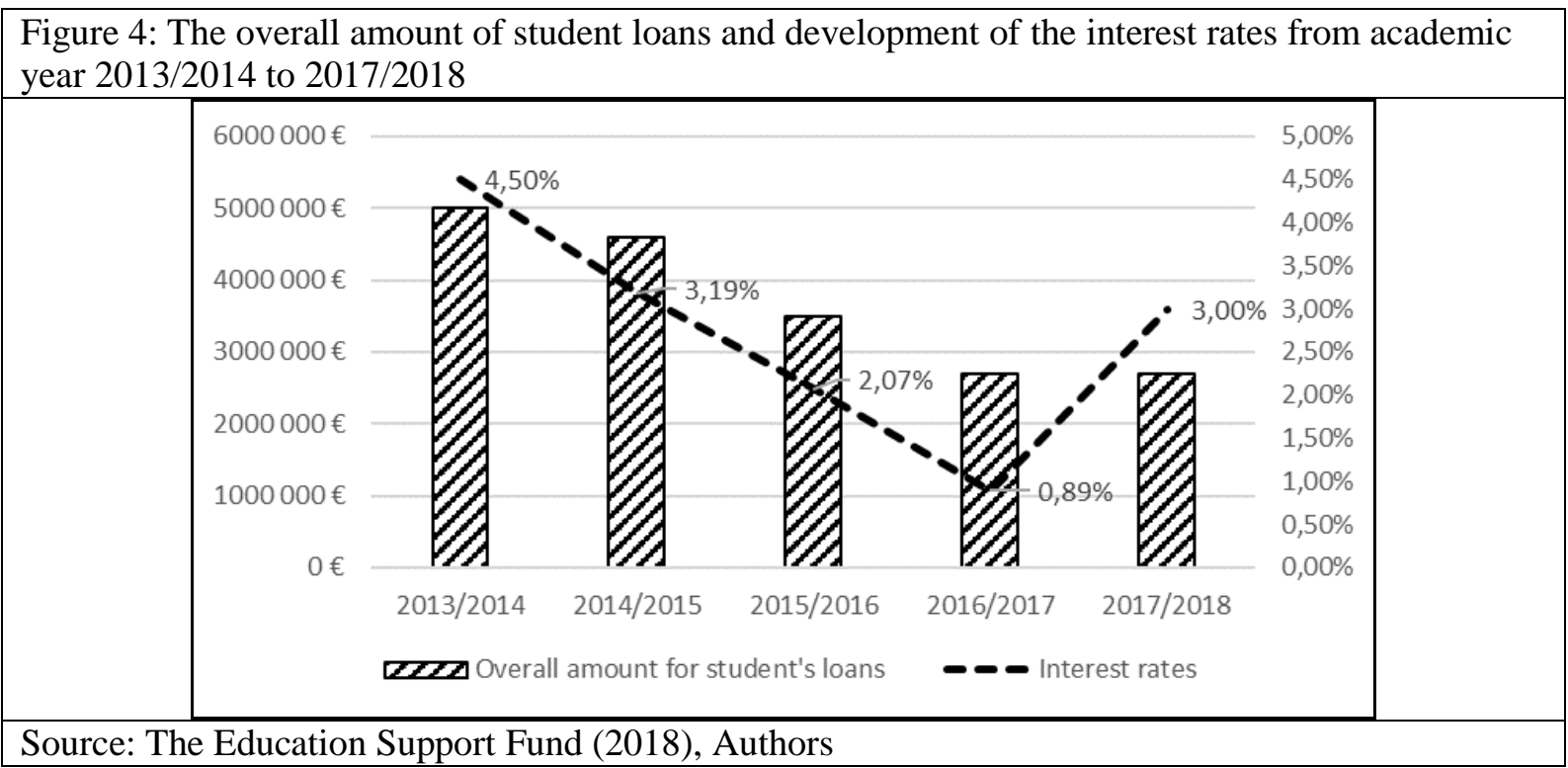

Figure 5 shows how the most important macroeconomic indicator developed from 2008 to 2016. The Slovak economy grew by $3.3 \%$ in 2016 , which compared to the previous year was around $0.5 \%$ lower (The National Bank of Slovakia, 2018a). Nevertheless, the Slovak economy reached the sixth highest growth in the European Union in 2016.

The net profit in the banking sector increased by $19.8 \%$ in 2016 (The National Bank of Slovakia, $2018 \mathrm{a})$. Adjusted for the exceptional factors, the sector's profitability declined by roughly $11 \%$ yearon-year.

Figure 6 shows the net profits reached by the Education Support Fund during the last five years. The highest net profit was achieved in the year 2017. The highest loss (EUR - 558 769) was caused by the 
partial remission of debts resulting from a change in law. The profitability of the Education Support Fund was significantly higher than in the banking sector. The net profit of the Education Support Fund increased by more than $25 \%$ in 2017.
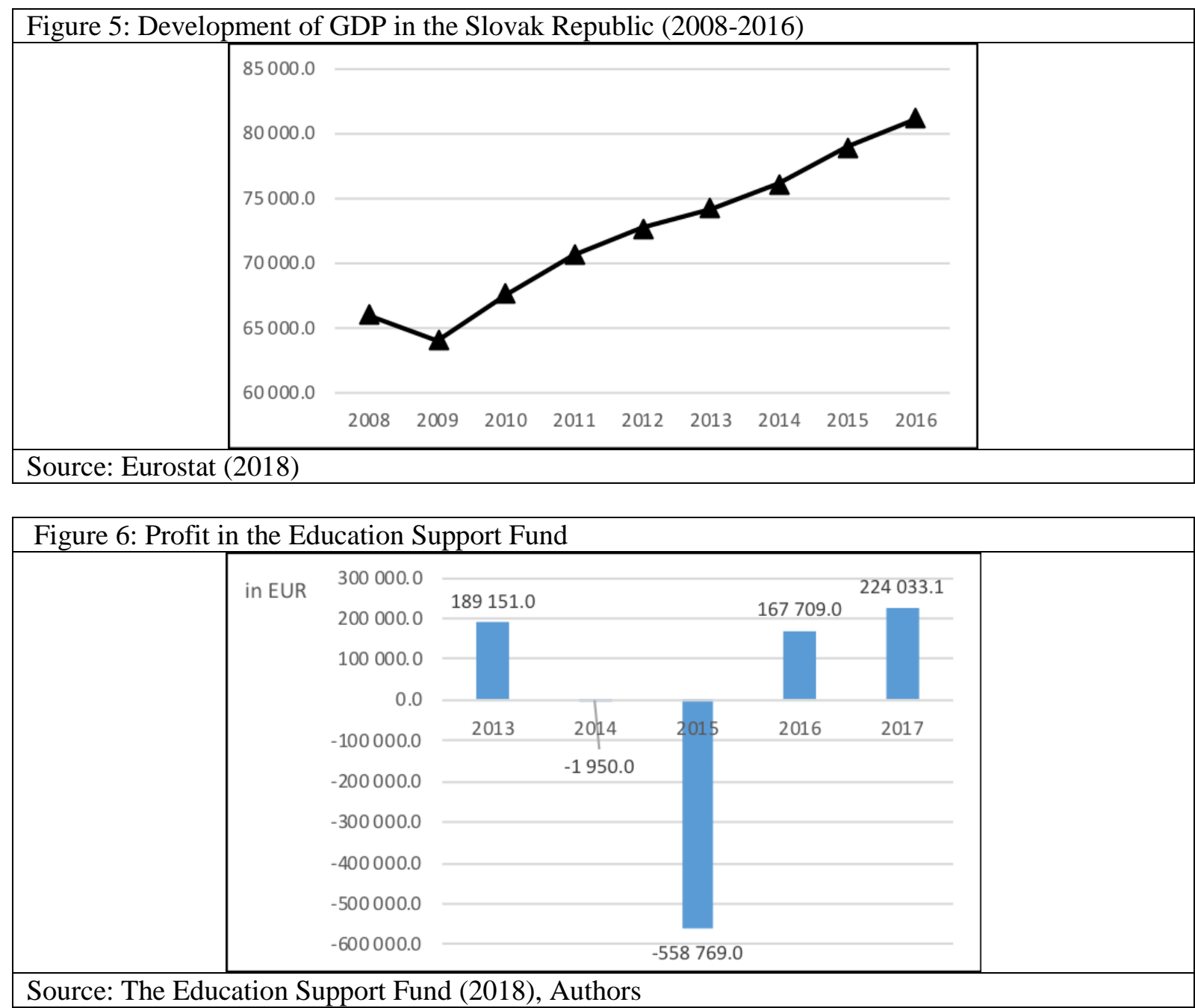

The share of student loans however, was influenced by the outstanding amounts of consumer credits, which are summarised in Table 1. The results achieved show the decreasing role of student loans subsidized by the state in the Slovak banking sector.

\begin{tabular}{|l|r|r|r|r|r|}
\hline Table 1: Share of the Student Loans in the Slovak Banking Market (in EUR million) \\
\hline Year & $\mathbf{2 0 1 3}$ & $\mathbf{2 0 1 4}$ & $\mathbf{2 0 1 5}$ & $\mathbf{2 0 1 6}$ & $\mathbf{2 0 1 7}$ \\
\hline Consumer credits in Slovakia & 3782 & 4276 & 4795 & 5518 & 6051 \\
\hline Student loans in Slovakia & 5 & 4,6 & 3,5 & 2,8 & 2,8 \\
\hline Share of student loans to consumer credits & $0,13 \%$ & $0,11 \%$ & $0,07 \%$ & $0,05 \%$ & $0,05 \%$ \\
\hline Source: The National Bank of Slovakia (2018b) \\
\hline
\end{tabular}

In 2017 the trends in the Slovak financial market reflected three significant factors: the sound performance of the domestic economy; rising asset prices in financial markets; and low or further declining interest rates (The National Bank of Slovakia, 2018a).

\section{Conclusion}

The loans subsidized by the state granted to Slovak full-time and part-time students and provided by the Education Support Fund are taken by about 1\% of students. The first major conclusion claims that the profitability of the Education Support Fund was significantly higher than in the banking sector in 2017. Adjusted for the exceptional factors, the bank sector's profitability declined by roughly $11 \%$ year-on-year. 
Due to the lack of financial resources, the overall amount of student loans has been decreasing from the beginning of the Education Support Fund. It will be possible to only grant loans of a maximum total of EUR 2.8 million per annum to tertiary students without a state financial grant or any kind of financial support. The key advantage of the student loans in comparison to the consumer credits is the favourable repayment conditions. The results achieved show the decreasing role of student loans subsidized by the state in the Slovak banking sector caused by the underfunded student loan system and the increasing interest for other types of consumer credits.

\section{References}

Arcand, J. L., Berkes, E. \& Panizza, U. (2015). Too much finance?. Journal of Economic Growth, 20(2), 105-148.

Beck, T., Büyükkarabacak, B., Rioja, F. \& Valev, N. (2012). Who Gets the Credit? And Does It Matter? Household vs. Firm Lending Across Countries. The B.E. Journal of Macroeconomics, 12(1), 1-46.

Cecchetti, S. G. \& Schoenholtz, K. L. (2015). Money, Banking and Financial Markets. New York, NY: McGraw-Hill Education.

Cifter, A. (2015). Bank concentration and non-performing loans in Central and Eastern European countries. Journal of Business Economics and Management, 16(1), 117-137.

Ding, L., Li, B. \& Feng, S. (2014). Research on Multiprincipals Selecting Effective Agency Mode in the Student Loan System. Mathematical Problems in Engineering, 2014, 1-8.

European Banking Federation. (2018, February 12). Slovakia's banking sector: Facts \& Figures. Retrieved from https://www.ebf.eu/europeanbankingsummit/slovakia/

Eurostat. (2018, February 15). GDP and main components (output, expenditure and income). Retrieved from http://appsso.eurostat.ec.europa.eu/nui/show.do?dataset=nama_10_gdp\&lang=en

Goenner, C. F. (2018). The market for private student loans: an analysis of credit union exposure, risk, and returns. Review of Quantitative Finance and Accounting, 50(4), 1227-1251.

Heitor, M., Horta, H. \& Leocadio, M. (2016). Enlarging the social basis of higher education: Lessons learned from extending a social support system with a risk-sharing loan scheme in Portugal. Technological Forecasting and Social Change, 113,319 -327 .

Henager, R. \& Wilmarth, M. J. (2018). The Relationship between Student Loan Debt and Financial Wellness. Family \& Consumer Sciences Research Journal, 46(4), 381-395.

Miller, J. J. \& Nikaj, S. (2018). Student loan debt, educational attainment, and tenure choice. Education Economics, 26(4), $393-410$.

Rentková, K., Panevski, D. (2017). The financial sector and economic development. Vision 2020: sustainable economic development, innovation management, and global growth (s. 4004-4017). Norristown: IBIMA.

Sahay, R. et al. (2015, May 4). Rethinking Financial Deepening: Stability and Growth in Emerging Markets. Retrieved from https://www.imf.org/en/Publications/Staff-Discussion-Notes/Issues/2016/12/31/Rethinking-Financial-Deepening-Stabilityand-Growth-in-Emerging-Markets-42868

The International Monetary Fund. (2018, January 10). Global Financial Stability Report, October 2016: Fostering Stability in a Low-Growth, Low-Rate Era. Retrieved from

https://books.google.sk/books?id=VpVsDQAAQBAJ\&printsec=frontcover\&source=gbs_ge_summary_r\&cad=0\#v=onepage $\& \mathrm{q} \& \mathrm{f}=$ false

The Education Support Fund. (2018, February 11). Annual report for 2016. Retrieved from http://www.fnpv.sk/vyrocnasprava-2016

The National Bank of Slovakia. (2018a, January 12). Analysis of the Slovak Financial Sector 2016. Retrieved from https://www.nbs.sk/_img/Documents/_Dohlad/ORM/Analyzy/ASFS_2016.pdf

The National Bank of Slovakia. (2018b, January 11). Consumer loans. Retrieved from https://www.nbs.sk/en/monetarypolicy/macroeconomic-database/macroeconomic-database-chart

The National Bank of Slovakia. (2018c, February 16). Loans - Breakdown by All Sectors - Outstanding Amounts. Retrieved from https:/www.nbs.sk/sk/statisticke-udaje/financne-institucie/banky/statisticke-udaje-penaznych-financnychinstitucii/uvery

The World Bank. (2018a, February 9). Bank nonperforming loans to total gross loans (\%). Retrieved from https://data.worldbank.org/indicator/FB.AST.NPER.ZS

The World Bank. (2018b, February 10). Domestic credit provided by financial sector (\% of GDP). Retrieved from https://data.worldbank.org/indicator/FS.AST.DOMS.GD.ZS

The World Bank. (2018c, February 8). Domestic credit provided by financial sector (\% of GDP) - Metadata. Retrieved from http://databank.worldbank.org/data/Views/Metadata/MetadataWidget.aspx?Name=Domestic $\% 20 \mathrm{credit} \% 20 \mathrm{provided} \% 20 \mathrm{by} \%$ 20financial\%20sector $\% 20(\% \% 20$ of $\% 20$ GDP $) \& C o d e=F S . A S T . D O M S . G D . Z S \& T y p e=S \& R e q T y p e=M e t a d a t a \& d d 1 S e l e c t e d V$ alue $=$ IND $\&$ ReportID $=62602 \&$ ReportType $=$ Table 